\title{
Małgorzata Syrek
}

Uniwersytet Łódzki

https://doi.org/10.18778/8142-463-9.07

\section{Kreatywność językowa użytkowników jeździeckich forów internetowych}

Badania nad środowiskowymi odmianami języka są prowadzone od dawna - przyczynia się do tego różnorodność i wielość zainteresowań oraz ciągłe powstawanie nowych sportów czy zamiłowań. Socjolektem nazywa się mowę małej grupy społecznej: terytorialnej, zawodowej, religijnej, towarzyskiej itp., wyróżniającą się zespołem charakterystycznych właściwości [Głowiński 2002: 515]. Warunkami jego istnienia są m.in. środowisko społeczne z silnymi więzami wewnątrzgrupowymi, względna stabilność grupy, ciągłe poczucie odmienności w stosunku do innych grup czy częste kontakty członków grup. Interesująco prezentuje się na tym tle socjolekt jeździecki, który nie doczekał się zbyt wielu opracowań językoznawczych. Z istniejących prac na ten temat warto wymienić słownik Zdzisława Baranowskiego Koń i jeździectwo. Polsko-angielsko-francusko-niemiecki stownik hipologiczny oraz nieopublikowaną pracę magisterską z 2001 roku autorstwa Katarzyny Nysiak pt. Socjolekt jeździecki w różnych sytuacjach komunikacyjnych, która jest istotną próbą opracowania słownika tego środowiska. Ponadto dysponujemy rozwiniętym źródłem informacji, jakim jest internet, a w nim kilka serwisów, na których udzielają się osoby znane w jeździectwie - trenerzy i instruktorzy z wieloletnim stażem, hodowcy czy behawioryści. Należy do nich m.in. 
hipologia.pl - portal, na którym znajdziemy odniesienia np. do Pro Hipico Bono - stowarzyszenia prowadzącego Uniwersytet Pro Hipico Bono (potocznie można go określić uniwersytetem jeździeckim).

Materiał, który poddałam analizie, pochodzi z internetowych forów jeździeckich hipologia.pl oraz volta.pl. Z wypowiedzi internautów wybrałam słowa charakterystyczne dla badanego środowiska. W pierwszym etapie badań dokonałam weryfikacji materiału na podstawie własnej wiedzy wynikającej z wieloletniego przebywania w otoczeniu jeździeckim. Następnie obecność każdego z leksemów i połączeń sprawdziłam w wybranych pozycjach leksykologicznych: Stownik hipologiczny (SH), Stownik socjolektu jeździeckiego (SSJ) i Uniwersalny słownik języka polskiego (USJP) pod. red. Stanisława Dubisza. Dodatkowo wykorzystałam słowniki frazeologiczne oraz Narodowy korpus języka polskiego.

Wybór tematyki wpisów internautów ograniczyłam do zagadnień podstawowych, takich jak obrządek konia, przygotowanie do jazdy konnej i typowe problemy w kontakcie między jeźdźcem a koniem oraz ogólne pytania o dyscypliny jeździeckie.

Jest to opracowanie, która wyodrębnia słownictwo internautów charakterystyczne dla środowiska jeździeckiego, ale niepojawiające się w języku ogólnym. Zbadałam znaczenie użytych zwrotów. Materiał obejmuje odmiany języka reprezentatywne dla terytorium całego kraju, ponieważ zasięg forów jest ogólnopolski.

Zgromadzony materiał to 65 słów i fraz. Wśród nich 34 to pojedyncze leksemy, a pozostałe to połączenia wyrazowe. Najliczniejszą grupę stanowią neofrazemy - 23 (np. dwuosobowe stado, zagalopowaćz lewej nogi, położyćsię na wędzidle, jeździćna luźnej wodzy, przytożyćtydkę), następne w kolejności są neologizmy - 9 (np. strychowanie, owijki, dosiad, podkuwacz). Całość materiału, który uznałam za przejaw kreatywności językowej użytkowników jeździeckich forów internetowych, prezentuje poniższa tabela (zestawienie w kolejności alfabetycznej). 


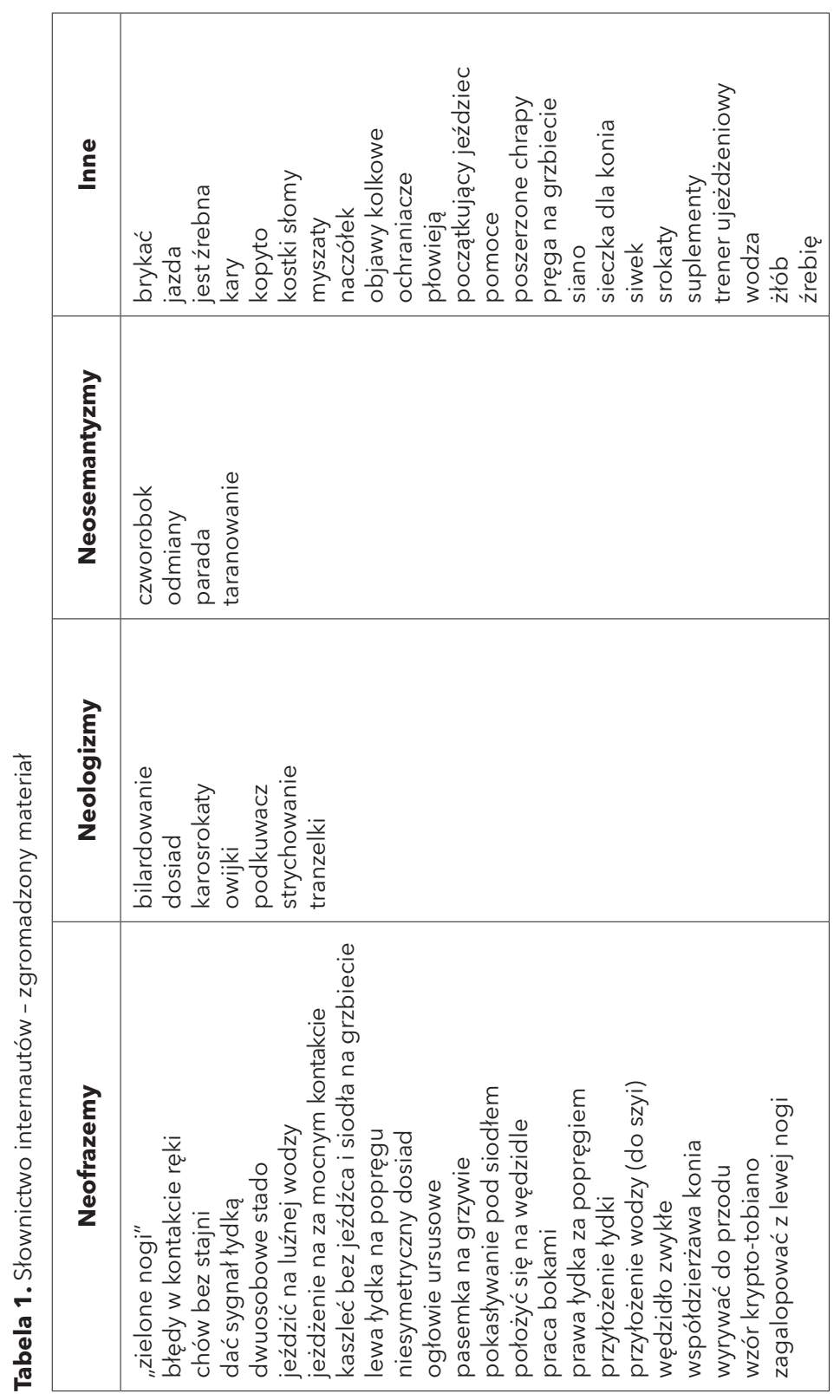

Kreatywność językowa użytkowników jeździeckich forów... 
Ze względu na ograniczone możliwości związane z objętością artykułu omówię jedynie kilka najbardziej reprezentatywnych i w mojej opinii najciekawszych przykładów.

Pierwszą wyodrębnioną przeze mnie grupą są frazemy. „Frazematyka jest odmianą frazeologii, która za punkt wyjścia przyjmuje człowieka mówiącego, [...] jest frazeologią nadawcy" [Chlebda 1993: 327]. W wymienionej już pracy magisterskiej dotyczącej socjolektu jeździeckiego wspomniano, że „stosunkowo często w stałych połączeniach wyrazowych używanych wśród koniarzy naruszane są zasady łączliwości wyrazów” [Nysiak 2001: 96]. Konieczność szybkiej i udanej komunikacji to potrzeba, na którą odpowiedzią są stałe połączenia wyrazowe. Większość nie występuje w słownikach. Ponieważ „jedynym kryterium, jakim operuje frazematyka, jest odtwarzalność elementu językowego w danej sytuacji i dla nazwania danej wiązki sensów” [Chlebda 1993: 327], a frazem to „każdy znak językowy, stanowiący nazwę potencjału treściowego (pojęcia), który w danej sytuacji dla wyrażenia tego potencjału mówiący przywołuje (odtwarza) w charakterze jego względnie stałego symbolu" [Chlebda 1991: 27], to frazy występujące w środowisku jeździeckim wydają się bardziej frazemami niż frazeologizmami w ujęciu tradycyjnej frazeologii.

Analiza frazemów tworzonych przez użytkowników forów jeździeckich przedstawia się następująco:

Przyciskanie do ściany to albo objaw lęku, albo braku hierarchii w dwuosobowym stadzie, jakim jest koń i człowiek. Pewne zasady trzeba wypracować na placu ${ }^{1}$.

Słowo stado występuje w słowniku S. Dubisza w znaczeniu 'gromada zwierząt danego gatunku, razem żyjących, pasących się, przebywających, hodowanych; także: gromada ptaków; żart.

$1 \mathrm{http}: / /$ www.hipologia.pl/forum/viewtopic.php? $\mathrm{f}=4 \& \mathrm{t}=3002$ (dostęp: 21.03.2018). 
chodzić stadami - o środkach komunikacji miejskiej: pojawiać się w dużej liczbie', jednocześnie, jednak połączenie dwuosobowe stado jest innowacją - nie jest odnotowane w analizowanych słownikach i leksykonach. Narodowy korpus języka polskiego po-

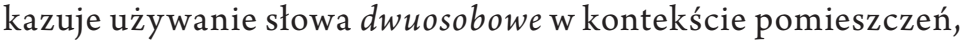
przedmiotów czy tworzonych przez ludzi grup (np. dwuosobowe tóżko, pokoje, dwuosobowa drużyna, zespót) - nie odnotowuje on połączenia ze słowem stado.

W środowisku jeździeckim frazem ten odnosi się do jeźdźca i konia - jako zespołu, relacji - połączonych więzią emocjonalną i temperowanego odpowiednimi regułami, a więc odnosi się nie tylko do zwierzęcia, lecz także do człowieka. Ta innowacja wskazuje na głębię relacji, jaka tworzy się między jeźdźcem i koniem.

Kolejny przykład neofrazemu:

Próbowałam ją [klacz] rozluźnić, jeździłam na luźnej wodzy i próbowałam skręcać od zewnętrznej².

Czasownik jeździćna łączy się w języku polskim z rzeczownikami w miejscowniku, np. jeździć na nartach, na rowerze, na deskach, na wózku, lub z rzeczownikami w bierniku, np. jeździć na studia, na działkę - czyli z tymi nazywającymi przedmioty używane do jazdy lub miejsca, do którego się jedzie. W dosłownym znaczeniu jazda na luźnej wodzy byłaby niemożliwa - ponieważ po pierwsze, jeździec jeździ na koniu, a po drugie, luźna wodza jest określeniem sposobu chwycenia za wodze, w tym wypadku w taki sposób, że koń odczuwa mały nacisk na pysku (gdyż wodze są połączone z wędzidłem umieszczonym w pysku konia podczas jazdy). Tego wyrażenia używa się, gdy mowa o jeździe na spiętym koniu i próbie rozluźnienia go. Określa się tak również koniec jazdy/treningu. Jest to zmiana okolicznika miejsca na okolicznik sposobu - kreatywność dotyczy semantyki.

2 http://www.hipologia.pl/forum/viewtopic.php?f=4\&t=3002 (dostęp: 21.03.2018). 
Następny frazem to przykład zawierający określenia charakterystyczne dla środowiska jeździeckiego:

Większość problemów z akceptacją kiełzna wynika ze zbyt twardej ręki lub z jeżdżenia na za mocnym kontakcie! ${ }^{3}$

Kiełzno ${ }^{4}$ to element, który pomaga zebrać konia. Jego przykładami są munsztuk, hackamore czy pelham. To słowo jest często mylone z wędzidłem, czyli kolejnym rodzajem kiełzna. Wędzidło jest metalowym prętem, do którego umocowane są lejce (wodze), wkładanym koniowi do pyska, umożliwiającym kierowanie zwierzęciem ${ }^{5}$ - wędzidło znajdziemy zarówno w USJP, jak i w Słowniku hipologicznym (z rozróżnieniem: wędzidło robocze, szkolne; wędzidło dźwigowe; wędzidło dodatkowe; wędzidło zwasami - z czankami (Baucher); wędzidło zawiasowe; wędzidło dla koni wyrzucających język) oraz w Stowniku socjolektu jeździeckiego (w ujęciu ogólnym).

Frazemy układają się w system relacji semantycznych. Jeżdżenie na za mocnym kontakcie jest przeciwieństwem jazdy na luźnej wodzy. Kontakt podczas jazdy konnej oznacza stopień porozumienia między jeźdźcem i koniem. Jednym z jego rodzajów jest działanie ręką (przez wodze/lejce) na pysk konia (przez wędzidło). Nacisk może być delikatny (wtedy można powiedzieć, że ktoś jeździ na luźnej wodzy), odpowiedni lub zbyt mocny - wówczas widać wzmożoną, nienaturalną reakcję konia (i spięcie jeźdźca), co daje negatywny skutek i dlatego używamy frazemu jeździć na ZA mocnym kontakcie. Narodowy korpus języka polskiego nie rejestruje połączenia mocny kontakt. W ujęciu ogólnym kontakt może być $z a-$ żył, bliski, bezpośredni, trwały, długi, jednak nie mamy w zwyczaju mówić, że jest mocny. Ta różnica wynika najprawdopodobniej

$3 \mathrm{http}: / /$ www.hipologia.pl/forum/viewtopic.php? $\mathrm{f}=4 \& \mathrm{t}=971$ (dostęp: 21.03.2018).

$4 \mathrm{http}: / /$ hejnakon.pl/?p=7695 (dostęp: 21.03.2018).

5 https://sjp.pwn.pl/sjp/;2535426 (dostęp: 21.03.2018). 
z przesunięcia znaczenia i nadania mu innej funkcji. Kiedy trener jeździectwa mówi jeździsz na za mocnym kontakcie, oznacza to nadmierne używanie pomocy, a nie zbyt zażyły kontakt z koniem. Kreatywność polega również na naruszeniu typowej łączliwości wyrazów z języka ogólnego.

Frazem twarda ręka można porównać $\mathrm{z}$ frazeologizmem żelazna ręka, który oznacza 'być surowym, wymagającym posłuszeństwa'6. Można byłoby uznać, że twarda ręka i jeździć na za mocnym kontakcie to wyrażenia synonimiczne, jednak uwagę zwraca lub użyte w przytoczonym przykładzie. Zdania współrzędnie złożone rozłączne wykluczają zawarte w sobie treści. Jeśli jeździec ma twardą rękę, oznacza to, że może być konsekwentny w stosowaniu dyscypliny (na pewno nieodpowiedniej w danym przypadku), a jeśli jeździ na za mocnym kontakcie, to znaczy, że świadomie lub nieświadomie nadużywa konkretnej pomocy, jaką są tutaj wodze. Podziały pól językowych są gęstsze niż w języku ogólnym. Subtelne rozróżnienia zrodziły potrzebę kreatywności.

Częstym zjawiskiem w słownictwie środowiska jeździeckiego są derywacje semantyczne. Jest to częsty sposób ubogacania słownictwa przez jego uczestników. „Przesunięcia dokonywane są na zasadzie podobieństwa w wyglądzie zewnętrznym, pokrewieństwa cech, powtarzalności sytuacji. Niektóre wyrazy dzięki zagarnięciu przez socjolekt poszerzają swój zakres, jednocześnie ograniczając treść, inne wręcz przeciwnie, poszerzając treść - ograniczają zakres" [Nysiak 2001: 64-65].

Wśród wyodrębnionych przeze mnie neologizmów można wyróżnić np. bilardowanie, strychowanie, dosiad, owijki, podkuwacz.

Pierwszym analizowanym przeze mnie wyrazem jest strychowanie.

Również nie słyszałam o strychowaniu przodem7.

6 http://www.edupedia.pl/words/index/show/475255_slownik_ frazeologiczny-miec_twarda_reke.html (dostęp: 21.03.2018).

7 http://www.voltahorse.pl/forum/viewtopic.php?f=1\&t=16335 (dostęp 21.03.2018). 
Strychowanie pochodzi od rzeczownika notowanego przez USJP strychulec i oznacza 'ocieranie jednej o drugą wewnętrznych części kończyn przednich lub tylnych w ruchu u konia, prowadzące do uszkodzenia pęcin; jest rezultatem niewłaściwego sposobu poruszania się konia'. Samo strychowanie znajdziemy w SH w znaczeniu 'zacinać się, strychować się' oraz w SSJ w formie 'o koniu: ocierać pęcinami o siebie w czasie ruchu’.

Kolejny przykład to słowo będące podstawą prawidłowej jazdy konnej-dosiad.

Tak samo jest gdy używam wodzy lub dosiadu' ${ }^{9}$.

Słowa dosiad nie rejestruje USJP, jednak pojawia się w SSJ (z rozróżnieniem na dosiad i dosiad ujeżdżeniowy) i w SH (z rozróżnieniem: dosiad, siad; dosiad normalny, szkolny; dosiad sportowy, pótsiad; dosiad wyścigowy; dosiad fotelowy; dosiad widłowy; dosiad sztywny; dosiad miękki; dosiad poprawny). Sam dosiad to 'układ ciała jeźdźca na koniu mający na celu optymalne rozłożenie ciężaru i zachowanie równowagi, umożliwiający kontrolę nad ruchami konia i podążanie za nimi' ${ }^{10}$. USJP odnotowuje jedynie słowo dosiadać, a więc dosiad to przykład neologizmu.

Wśród neosemantyzmów można wymienić czworobok, paradę, odmiany czy taranowanie.

Jak łatwo zapamiętać litery na czworoboku ${ }^{11}$.

Czworobok jest wyrazem odnotowywanym tylko w USJP w znaczeniu 'szyk bojowy oddziałów piechoty umożliwiający atak lub

8 https://pl.wikipedia.org/wiki/Strychowanie (dostęp: 21.03.2018).

9 http://www.hipologia.pl/forum/viewtopic.php? $\mathrm{f}=4 \& \mathrm{t}=3002$ (dostęp 20.03.2018).

$10 \mathrm{https://pl.wikipedia.org/wiki/Dosiad} \mathrm{(dostęp:} \mathrm{21.03.2018).}$

$11 \mathrm{http}: / /$ www.voltahorse.pl/forum/viewtopic.php? $\mathrm{f}=1 \& \mathrm{t}=1304$ (dostęp: 25.03.2018). 
obronę we wszystkich kierunkach, stosowany od starożytności do XIX wieku'. W drugim znaczeniu w USJP mamy odniesienie do czworokąta. Wspomnianego słowa nie znajdziemy w pozostałych słownikach wymienionych na początku artykułu. W socjolekcie jeździeckim oznacza on 'miejsce przeprowadzania konkursów w ujeżdżeniu (oznaczone literami alfabetu)'12. Przesunięcie znaczenia z czynności na miejsce jest kolejnym przejawem kreatywności internautów. W neosemantyzmie pozostaje nawiązanie do kształtu. Zarówno piechota, jak i miejsce odbywania się konkursów ujeżdżeniowych tworzą pewien układ przestrzeni. Piechota przemieszcza się podczas obrony czy ataku - przestrzeń jest elementem ruchomym. Na czworoboku ujeżdżeniowym jeździec wykonuje przygotowany układ figur - przestrzeń w tym kontekście jest elementem stałym.

Natomiast parada jest wyrazem występującym w każdym $\mathrm{z}$ trzech słowników, jednak nie zawsze w tym samym znaczeniu.

Litery pochodzą od nazwy punktu, gdzie w trakcie przygotowań do parady każdy uczestnik orszaku miał wyznaczone miejsce ${ }^{13}$.

W najstarszym ze źródeł leksykograficznych (SH) występuje pótparada, SSJ podaje definicję 'zebranie wodzy przy jednoczesnym napędzającym działaniu łydkami i krzyżem prowadzące do zatrzymania konia w każdym chodzie' [Nysiak 2001: 34], natomiast USJP podaje wyjaśnienia odnoszące się do uroczystych ceremonii czy do przeglądu wojsk. Wyraz parada pochodzi z języka hiszpańskiego (pierwsza połowa XVI wieku) i od początku odnosił się do jeździectwa w kontekście przeglądu wojsk, jednak w socjolekcie jeździeckim wykorzystuje się pierwotne znaczenie związane z zatrzymaniem się (od vb parar - zatrzymać) [Nysiak 2001: 71, 88]. Kreatywność

12 https://pl.wikipedia.org/wiki/Czworobok_(je\%C5\%BAdziectwo) (dostęp: 24.04.2018).

$13 \mathrm{http}: / /$ www.voltahorse.pl/forum/viewtopic.php? $\mathrm{f}=1 \& \mathrm{t}=1304$ (dostęp: 25.03.2018). 
polega na nadaniu omawianemu słowu roli innej od funkcjonującej w języku ogólnym - jednocześnie jest to też powrót do pierwotnego znaczenia.

Kolejny przykład neosemantyzmu to odmiana.

W paszporcie ma on wpisane, że jest „myszaty” z odmianami.

Na forach jeździeckich używa się tego słowa w odniesieniu do śladów innego koloru w maści konia. SSJ postrzega je w znaczeniu 'biała plama na ciele konia, może występować na głowie lub nogach, rzadziej w innym miejscu'. Narodowy korpus języka polskiego rejestruje 1161 użyć słowa odmiana, jednak przeglądając zawarte w nim przykłady, trudno znaleźć zastosowanie w kontekście maści konia. Odmiana w języku ogólnym to '1. uczynienie, stanie się innym, odmiennym; przemiana, zmiana; 2 odrębna postać, wariant czegoś'. Podaję dwa znaczenia spośród sześciu z USJP, ponieważ najlepiej obrazują podobieństwo znaczeniowe - pozostałe również odnoszą się do zmian różnych kontekstach, jednak żadne nie odnosi się do jeździectwa. Kreatywność przejawia się na poziomie semantyki oraz innowacji w łączliwości wyrazów.

Język środowiska jeździeckiego - w porównaniu do języka ogólnego - charakteryzuje większa kreatywność usytuowana na różnych poziomach. Dotyczy wielu podsystemów języka: składni, semantyki, łączliwości wyrazów.

Wymienione wyżej przykłady w pewnym stopniu odzwierciedlają kreatywność językową użytkowników jeździeckich forów internetowych. Subtelność kontaktu pomiędzy jeźdźcem i koniem, wktórym nie ma miejsca np. na wyrazy nacechowane emocjonalnie, przekłada się na drobne różnice pomiędzy znaczeniami w języku. Można uznać, że to była główna potrzeba, na którą odpowiedzią stała się zaprezentowana tu częściowo kreatywność. Czasami użytkownicy forów przenoszą wyrazy ze słownictwa ogólnego, a czasami tworzą zupełnie nowe słowa. Liczne nietypowe połączenia - neofrazemy, neosemantyzmy czy neologizmy - nie tylko wzbogacają ogólny zasób polszczyzny, lecz także budzą ciekawość. 
Nierzadko dużo bardziej precyzyjne definicje niż w słownikach książkowych można znaleźć w internecie. Świadczą o tym np. cytowane przeze mnie te $\mathrm{z}$ internetowej Wikipedii, które wybrałam nie tyle ze względu na prostą i jasną konstrukcję, ile na wierność rzeczywistości.

\section{Bibliografia}

Baranowski Z. [1989], Koń i jeździectwo. Polsko-angielsko-francusko-niemiecki stownik hipologiczny, Krajowa Agencja Wydawnicza, Wrocław.

Chlebda W. [1991], Elementy frazematyki, Studia i Monografie, Opole.

Chlebda W. [1993], Frazematyka, [w:] J. Bartmiński (red.), Encyklopedia kultury polskiej XX wieku. Wspótczesny język polski, Wiedza o Kulturze, Wrocław-Lublin.

Dobrowolska J., Kawa K. [2005], Stownik frazeologiczny, Wydawnictwo Europa, Wrocław.

Dubisz S. [2003], Uniwersalny stownikjęzyka polskiego, Warszawa.

Głowiński M., Okopień-Sławińska A. [2002], Słownik terminów literackich, Ossolineum, Wrocław.

Müldner-Nieckowski P. [2004], Wielki stownik frazeologiczny języka polskiego, Świat Książki, Warszawa.

Nysiak K. [2001], Socjolekt jeździecki w różnych sytuacjach komunikacyj$n y c h$, niepublikowana praca magisterska napisana pod kierunkiem prof. dr hab. Anny Krupskiej-Perek, Uniwersytet Łódzki, Łódź.

\section{Strony internetowe}

http://edupedia.pl (dostęp: 21.03.2018).

http://hejnakon.pl (dostęp: 21.03.2018).

http://hipologia.pl (dostęp: 21.03.2018).

http://nkjp.pl (dostęp: 21.03.2018).

http://sjp.pwn.pl (dostęp: 21.03.2018).

http://voltahorse.pl (dostęp: 21.03.2018).

http://wikipedia.org (dostęp: 21.03.2018). 